\title{
Research on the influence of the five-axis ball-burnishing process regime parameters on the resulted cells properties from regularly shaped roughness
}

\author{
Iliyan Velichkov Iliev ${ }^{1}$ \\ 1 - Technical University of Varna, Department of Mechanical Engineering and Machine Tools, 9010, 1 Studentska Street, Varna, Bulgaria \\ Corresponding author contact: iliev170@abv.bg
}

\begin{abstract}
The current study presents the results from the experimental research conducted on the influence of the regime parameters on the process for a five-dimensional Ball Burnishing (BB) finishing process with the help of a CNC milling machine on the Regular Reliefs (RR) obtained on complex functional surfaces. The elements of the technological system, necessary for the formation of RR of type IV on the complex surfaces, are presented. A planned factorial experiment is realized, through which the significantly affecting parameters of the BB process on the size and shape of the $R R$ cells, are determined. The results obtained are statistically confirmed by a dispersion analysis (ANOVA) carried out. Conclusions, regarding the possibilities of obtaining RRs of type IV on complex surfaces through a process of five-axis simultaneous $B B$, are made.
\end{abstract}

Keywords: finishing processing, regular relief, surface plastic deformation, simultaneous multiaxis operations, CNC milling machine

\section{Introduction}

A large number of the details, used in the modern machine industry, plastics industry, power engineering, heating and ventilation equipment as well as in the various means of transport in order to fulfil their functional purpose, need to have surfaces of a complex shape, different from the most common cylindrical, conical and/or planar surfaces. Examples of such details are injection molds, pump impellers, turbine blades, propellers of the sailing vessels, construction elements of the engines of cars, trains, planes, etc. (Shiou \& Chen, 2003; Shiou \& Chen, 2010; Иванов, Опокин, Равилов \& Самойленко, 2014; Климов, Жаткин, Щедрин \& Когтева, 2015; Кравченко, 1978; Локалов \& Марковский, 2016; Петрова, Мехди \& Тарасов, 2015; Таскаев, 2010). Their operational characteristics depend largely on the macro shape, which they are constructively designed to have and the material they are made of. Often, however, the condition of their surface layer also has a significant influence, through the quality parameters, such as: size and texture of roughness, residual tension in the surface layer, hardness, oil retention capability, fluid flow resistance, corrosion resistance, etc.

There are numerous examples in the technological practice for studies, which show that the reliefs, produced through a process of vibration surface plastic deformation (VBB) both on planar and cylindrical functional surfaces, optimize to a great extent the operational characteristics of the details, processed via this method (Георгиев, Славов \& Димитрова, 1999; Георгиев \& Славов, 2003a, 2003b, 2003c; Славов, 2014; Сучков, Кьршаков \& Костадинов, 1980; Akkurt and Oval1, 2014; Sagbas, 2011; Odintsov, 1987; Rodríguez, López de Lacalle, Celaya, Fernzndez \& Lamikiz, 2011; Gharbi et all, 2015; Grochała, Berczyński \& Grządziel, 2014; Maximov, Anchev, Duncheva, Ganev \& Selimov, 2016; Loh,Tam and Miyazawa, 1989a, 1989b; Babu, Ankamma, Prasad, Raju \& Prasad, 2012; Prevéy, Jayaraman \& Cammett 2005; Schneider, 2001, Slavov \& Dimitrov, 2016, 2018). In the process of machining, a deforming element (of a spherical or cylindrical shape) moves on a complex (close to a sinusoidal) trajectory, pressing with a certain force on the machined surface (Schneider, 2001). As a result, overlapping traces of a material with plastic deformation are obtained on the surface of the machined detail. Thus, the so called "regular relieves" (RR) are formed that have a specific texture of the roughness, as well as improved physical and mechanical characteristics of the surface layer. 
With the introduction of MM with CNC control and the computer software system for automatic design (Computer Aided Design - CAD), and the computerized preparation of the manufacturing (Computer Aided Manufacturing - CAM) methods for obtaining RR through a BB process are developed, realized with the help of such equipment (Славов, 2010a, 2010b, 2014; Rodríguez et al., 2011). They do not need the deforming element to vibrate in order to obtain a RR of the desired type, and the required sinusoidal trajectory is achieved by mathematical generation of the tool path and its subsequent programming in a program for MM with CNC (Slavov, 2017, 2018). The source (Rodríguez et al., 2011) shows an example for the implementation of the BB process for finishing processing of different surfaces and types of materials, used in the Machine industry with the help of MM with CNC. All of them, however, are related to studying the possibilities of the so-called "smooth" BB, where the process is used to reduce the surface roughness and to form certain physical-mechanical characteristics in the surface layer. There is no evidence in the specialized literature that the BB has been used to form RR of type IV on complex non-planar surfaces.

For this reason, the main objective of the present work is to study the possibilities of obtaining RR of type IV on complex surfaces by means of the BB process, realized on a five-axis MM with CNC and to determine the influence of the basic regime parameters on the characteristics of the cells of the relief.

\section{Methodology for experimental study of the influence of the regime parameters on the five-axis BB process on the size and the shape of the obtained RR cells of type IV.}

\subsection{Elements of the technological system for formation of RR of type IV on complex functional surfaces -}

The technological provision of the operation for the implementation of multi-axis BB on complex functional surfaces in order to obtain RR type IV, using modern MM with CNC includes:

- A specially designed BB tool (see pos.1 fig. 1, a), that allows adjustment and measurement of the instantaneous value of the deforming force $\mathrm{F}, \mathrm{N}$, as well as changing the diameter of the deforming elements in a certain range $(\mathrm{dc}=5-8, \mathrm{~mm})$ (Slavov \& Iliev, 2016);
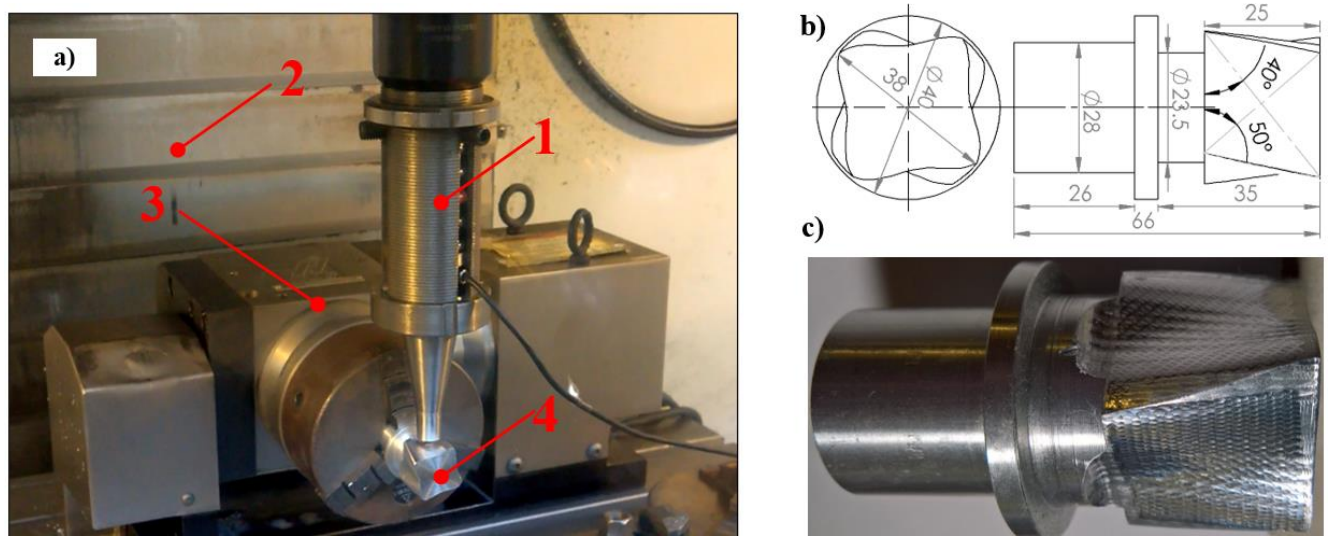

Fig. 1. a) Technological system for five-axis BB operation on complex surfaces; b) Drawing of the experimental specimen; c) Experimental specimen, with formed RR of type IV on the side surfaces through five-axis BB process.

- Three-axis milling machine HASS, model VF-3 (see pos. 2 of Fig. 1,a), equipped with two-axis rotating table HAAS, model TR-110 (see pos. 3 of Fig. 1,a), the two components forming a five-axis processing machine with simultaneous control of the five axis;

- CAM software (NX Siemens) for modeling the required trajectory of the movement of the deforming tool and generating the corresponding control program for the multi-axis MM with CNC;

- Test specimens (see pos. 4 of Fig. 1, a) of duralumin, mark 2024-Т3 (БДС EN 754-3:2008), which have the shape and the size, shown on Fig. 1, b, on whose side surfaces with complex shape, RR of type IV are formed through the process of five-axis BB operation (see Fig. 1, c). 


\subsection{Methodology of the experimental study}

In order to achieve the experimental objective of the present study, the methodology of the planned factor experiments (Montgomery, 2017) is used. The study of the references (Odintsov, 1987; Shneider, 2001; Slavov \& Dimitrov, 2018) leads to identifying four main influencing parameters of the process on the characteristics of the resulting RR on the surfaces processed. They are, as follows:

- $\mathbf{d}_{\mathbf{b}}, \mathbf{m m}$ - diameter of the hard-deforming element used (i.e. of the ball bearing);

- F, $\mathbf{N}$ - the pre-set (nominal) deforming force, applied to the deforming element of the spring of the tool;

- $\mathbf{e}, \mathbf{m m}$ - the set half of the amplitude of the sinusoidal trajectory, on which the tip of the deforming tool moves. This regime parameter defines the size of the RR cells in horizontal direction;

- $\mathbf{i}$ - the set value of the number of the sine waves, within the length of the trajectory $\pi^{*}$ Do, mm. This regime parameter defines the length of the period of the sine waves from the motion trajectory and hence the size of the RR cells in vertical direction;

Table 1. Design of the full factorial experiment of the type $2^{4}$

\begin{tabular}{|c|c|c|c|c|c|c|c|c|}
\hline \multirow{2}{*}{ № } & \multicolumn{4}{|c|}{ Full factorial experiment - encoded values } & \multicolumn{4}{|c|}{ Full factorial experiment - real values } \\
\hline & $d_{b,(m m)}$ & $F,(N)$ & $e,(\mathrm{~mm})$ & $i$ & $d_{b,}(\mathrm{~mm})$ & $F,(N)$ & $e,(\mathrm{~mm})$ & $i$ \\
\hline 1 & -1 & -1 & -1 & -1 & 6 & 250 & 0.5 & 1650.15 \\
\hline 2 & -1 & -1 & -1 & 1 & 6 & 250 & 0.5 & 2500.15 \\
\hline 3 & -1 & -1 & 1 & -1 & 6 & 250 & 1 & 1650.15 \\
\hline 4 & -1 & -1 & 1 & 1 & 6 & 250 & 1 & 2500.15 \\
\hline 5 & -1 & 1 & -1 & -1 & 6 & 380 & 0.5 & 1650.15 \\
\hline 6 & -1 & 1 & -1 & 1 & 6 & 380 & 0.5 & 2500.15 \\
\hline 7 & -1 & 1 & 1 & -1 & 6 & 380 & 1 & 1650.15 \\
\hline 8 & -1 & 1 & 1 & 1 & 6 & 380 & 1 & 2500.15 \\
\hline 9 & 1 & -1 & -1 & -1 & 8 & 250 & 0.5 & 1650.15 \\
\hline 10 & 1 & -1 & -1 & 1 & 8 & 250 & 0.5 & 2500.15 \\
\hline 11 & 1 & -1 & 1 & -1 & 8 & 250 & 1 & 1650.15 \\
\hline 12 & 1 & -1 & 1 & 1 & 8 & 250 & 1 & 2500.15 \\
\hline 13 & 1 & 1 & -1 & -1 & 8 & 380 & 0.5 & 1650.15 \\
\hline 14 & 1 & 1 & -1 & 1 & 8 & 380 & 0.5 & 2500.15 \\
\hline 15 & 1 & 1 & 1 & -1 & 8 & 380 & 1 & 1650.15 \\
\hline 16 & 1 & 1 & 1 & 1 & 8 & 380 & 1 & 2500.15 \\
\hline
\end{tabular}

A full factorial experiment design of the type $2^{4}$ is used to conduct the study. This factorial design includes four factors, which change in two levels - low and high (Montgomery, 2017). This experimental design is orthogonal and has 16 unique combinations of low and high levels of the contributing factors. The combinations of the values in encoded and natural values of the regime parameters of the process for five-axis BB operation are shown in Table 1.

\subsection{Methodology for determining the shape and size of $R R$ cells}

As a measuring instrument for studying the shape and size of the resulting RR cells on the non-planar surface, a DigiMicro Lab 5.0+ digital microscope (dnt, Germany), is used, for obtaining digital images of the processed through five-axis BB operation surfaces with a high resolution (12 MPix) and a specialized software, allowing the measurement of the size and the shape parameters of the RR cells. The microscope is capable of maximum magnification of $\times 500$ times and allows recording of the images captured directly on an external computer via a USB 2.0 serial port.

Fig. 2 shows the measuring device for determining the geometrical parameters of the RR cells, formed on the processed specimen's surfaces. The processed through five-axis BB operation specimen (see pos. 1) is positioned on the worktable of the digital microscope (see pos. 2), fixed towards the lens by means of plastilin mats. The table of the microspore can be moved up and down in vertical direction, adjusting the level of the magnification of the obtained image of RR, as well as the number of cells included in the digital image. Thus, the set focused image of RR is captured and sent via USB port to a 
specialized software for processing. Each of the four surfaces with RR of the 16 experimental specimen is put on the table of the microscope, as described above and a digital image of the RR is taken.

The calibration of the digital microscope is performed, using the etalon calibration ruler from the set it comes with, in accordance with the manufacturer's methodology, separately for each image captured, by calculating the corresponding magnification factor, which is then used to recalculate the measured distances and calculate their values with a dimension millimeter.

Through the methodology described above, digital images of RR, shown on Fig. 3, are obtained. They serve as the basis for measuring the dimensions of the RR cells.

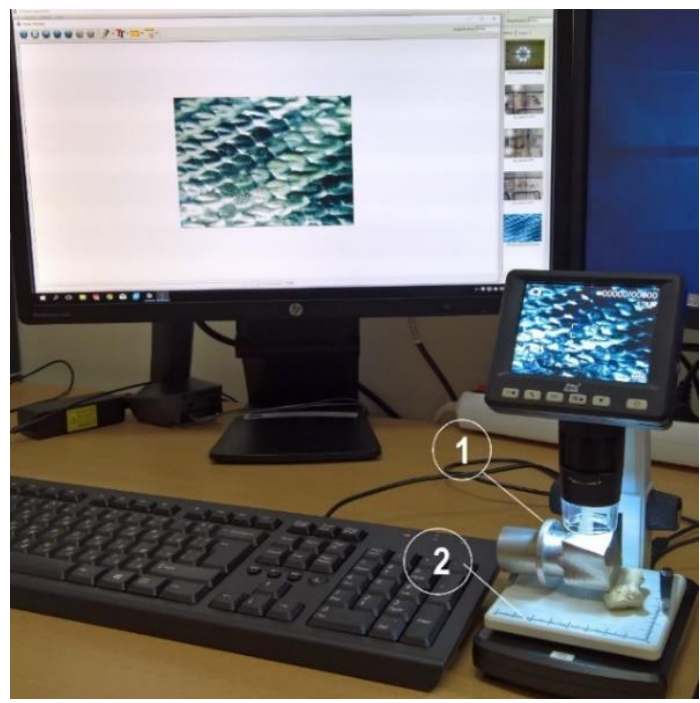

Fig. 2. Digital microscope Digilab5.0+, connected to a computer to obtain RR images of high resolution

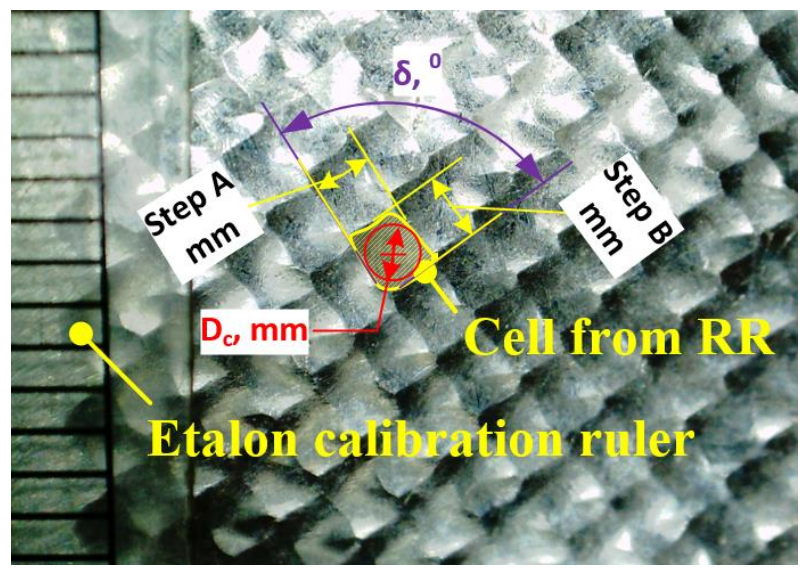

Fig. 3. Digital image of RR with cells with a rectangular shape via digital microscope DigiMicro Lab 5.0+ with indicated parameters of the cell to be measured.

For the purposes of the present study, the following parameters of the sizes of RR cells are measured (shown on Fig. 3):

- Step A, mm, which is the distance between the adjacent cell-forming structures in ascending direction of their alignment on the processed surface;

- Step B, mm, which is the distance between the adjacent cell-forming structures in direction of their alignment on the processed surface;

- Diameter Dc, mm, of the inscribed, within the cell borders, circumference

- Angle $\delta,{ }^{0}$, between two adjacent cell-forming structures, through which the distortion of its shape is monitored

The RR cells are formed both by the set parameters of the motion trajectory of the deforming element, and the obtained plastic deformation of the surface layer of the material. Whereas the overlapping of the motion trajectory on the processed surface, when processing by BB process on CNC milling machine of planar surfaces is with a high repeatability, which results in obtaining RR cells with very close sizes and shape, the plastic deformation of the material in the surface layer is a nonlinear process.

In spite of the fact that the RR cells, formed by the five-axis scheme for BB of non-planar surfaces, shown on Fig. 3 appear to be of the same shape and size, the plastic deformation, in combination with the processing of non-planar surfaces, can result in certain changes of some of the parameters of their sizes.

As on each processed surface of the experimental specimens a numerous cells are formed (in the range of several hundreds), measuring the size of each one of them is not possible. That is why the above-mentioned parameters are measured for five randomly chosen cells within the processed nonplanar surface. For these five cells the values of steps A and B, the diameter of the inscribed within the cell circumference and the angle between the adjacent cell-forming structures for the 16 specimens on 
their 4 sides, are measured. The measurement data are recorded in specially formatted MS Excel tables, in the form of table 2 .

Table 2. The measured values of steps A and B, the diameter Dc of the inscribed within the cell circumference and the angle $\delta$ between the adjacent cell-borders for experimental specimen No.1.

\begin{tabular}{|c|c|c|c|c|c|c|c|c|}
\hline & & RR cells parameters & Cell 1 & Cell 2 & Cell 3 & Cell 4 & Cell 5 & Mean \\
\hline & & Step A, mm & 0,66 & 0,67 & 0,75 & 0,59 & 0,67 & $\mathbf{0 , 6 7}$ \\
\hline & Side 1 & Step B, mm & 0,97 & 0,94 & 0,92 & 1,01 & 0,90 & 0,95 \\
\hline & $\begin{array}{l}\text { Magn. } \\
\times 11096\end{array}$ & Diameter- Dc, $\mathrm{mm}$ & 0,36 & 0,35 & 0,37 & 0,33 & 0,34 & $\mathbf{0 , 3 5}$ \\
\hline & & Angle $\delta,^{0}$ & 88,20 & 98,17 & 95,36 & 93,08 & 89,23 & 92,81 \\
\hline & & Step A. mm & 0.58 & 058 & 0.63 & 058 & 0.57 & 0.59 \\
\hline & Side 2 & Step B, mm & 0,89 & 0.85 & 0,89 & 0,93 & 0.86 & $\mathbf{0 , 8 8}$ \\
\hline & Magn. & Diameter- Dc, mm & 0,33 & 0,33 & 0,33 & 0,32 & 0,33 & $\mathbf{0 , 3 3}$ \\
\hline$\overbrace{2}^{010}$ & & Angle $\delta,^{0}$ & 89,91 & 86,81 & 88,63 & 82,71 & 89,58 & 87,53 \\
\hline है & & Stan $\mathrm{mm}$ & 0.50 & 062 & 0.63 & 075 & 062 & 064 \\
\hline क & Side 3 & Step B, mm & 0,85 & 0,86 & 0,90 & 0,85 & 0.91 & 0,87 \\
\hline & Magn. & Diameter- Dc, mm & 0,34 & 0,35 & 0,36 & 0,37 & 0,38 & 0,36 \\
\hline & & Angle $\delta, 0$ & 100,32 & 99,67 & 92,45 & 97,30 & 94,05 & 96,76 \\
\hline & & Step A, mm & 0,81 & 0,64 & 0,65 & 0,63 & 0,63 & 0,67 \\
\hline & Side 4 & Step B, mm & 0,81 & 0,81 & 0,96 & 0,87 & 0,90 & 0,87 \\
\hline & Magn. & Diameter- Dc, $\mathrm{mm}$ & 0,34 & 0,35 & 0,36 & 0,35 & 0,35 & 0,35 \\
\hline & & Angle $\delta, 0$ & 92,95 & 87,70 & 89,89 & 88,96 & 85,99 & 89,10 \\
\hline
\end{tabular}

\section{Results from the experimental study}

3.1 Identifying the influence of the regime parameters of the $B B$ process on the main parameters and the shape of the cells of the obtained RR

The obtained arithmetic mean values for the parameters of the cells steps A and B, diameter Dc and angle $\delta$, are shown in Tables 3 to 6 , for the 16 specimens with a four-fold repetition of each row in the factor plan.

Table 3. Results for step A of the RR cells in the experimental plan

\begin{tabular}{|c|c|c|c|c|c|c|c|c|}
\hline \multirow{2}{*}{ Run } & \multicolumn{4}{|c|}{ Experimental design } & \multicolumn{4}{c|}{ Experimental results (trials) } \\
\cline { 2 - 9 } & $\mathbf{d}, \mathbf{m m}$ & $\mathbf{F , ~ N}$ & $\mathbf{e}, \mathbf{m m}$ & $\mathbf{i}$ & $\begin{array}{c}\text { Step A, mm } \\
\text { (Side 1) }\end{array}$ & $\begin{array}{c}\text { Step A, mm } \\
\text { (Side 2) }\end{array}$ & $\begin{array}{c}\text { Step A, mm } \\
\text { (Side 3) }\end{array}$ & $\begin{array}{c}\text { Step A, mm } \\
\text { (Side 4) }\end{array}$ \\
\hline 1 & 6 & 250 & 0.5 & 1650.15 & 0.67 & 0.59 & 0.64 & 0.67 \\
\hline 2 & 6 & 250 & 0.5 & 2500.15 & 0.49 & 0.54 & 0.59 & 0.64 \\
\hline 3 & 6 & 250 & 1 & 1650.15 & 0.99 & 0.88 & 1.03 & 1.00 \\
\hline 4 & 6 & 250 & 1 & 2500.15 & 0.85 & 0.80 & 0.90 & 1.17 \\
\hline 5 & 6 & 380 & 0.5 & 1650.15 & 0.55 & 0.69 & 0.55 & 0.61 \\
\hline 6 & 6 & 380 & 0.5 & 2500.15 & 0.67 & 0.71 & 0.70 & 0.57 \\
\hline 7 & 6 & 380 & 1 & 1650.15 & 1.13 & 1.11 & 1.02 & 1.07 \\
\hline 8 & 6 & 380 & 1 & 2500.15 & 0.62 & 0.73 & 0.72 & 0.83 \\
\hline 9 & 8 & 250 & 0.5 & 1650.15 & 0.60 & 0.58 & 0.62 & 0.63 \\
\hline 10 & 8 & 250 & 0.5 & 2500.15 & 0.59 & 0.51 & 0.57 & 0.59 \\
\hline 11 & 8 & 250 & 1 & 1650.15 & 0.95 & 1.00 & 1.07 & 1.03 \\
\hline 12 & 8 & 250 & 1 & 2500.15 & 1.05 & 1.09 & 1.17 & 1.10 \\
\hline 13 & 8 & 380 & 0.5 & 1650.15 & 0.63 & 0.58 & 0.59 & 0.58 \\
\hline 14 & 8 & 380 & 0.5 & 2500.15 & 0.57 & 0.51 & 0.54 & 0.55 \\
\hline 15 & 8 & 380 & 1 & 1650.15 & 0.99 & 1.05 & 0.96 & 1.05 \\
\hline 16 & 8 & 380 & 1 & 2500.15 & 0.89 & 0.97 & 0.91 & 0.99 \\
\hline
\end{tabular}


Table 4. Results for step B of the RR cells in the experimental plan

\begin{tabular}{|c|c|c|c|c|c|c|c|c|}
\hline \multirow{2}{*}{ Run } & \multicolumn{4}{|c|}{ Experimental design } & \multicolumn{4}{c|}{ Experimental results (trials) } \\
\cline { 2 - 9 } & $\mathbf{d b}, \mathbf{m m}$ & $\mathbf{F , ~ N}$ & $\mathbf{e}, \mathbf{m m}$ & $\mathbf{i}$ & $\begin{array}{c}\text { Step B, mm } \\
\text { (Side 1) }\end{array}$ & $\begin{array}{c}\text { Step B, mm } \\
\text { (Side 2) }\end{array}$ & $\begin{array}{c}\text { Step B, mm } \\
\text { (Side 3) }\end{array}$ & $\begin{array}{c}\text { Step B, mm } \\
\text { (Side 4) }\end{array}$ \\
\hline 1 & 6 & 250 & 0.5 & 1650.15 & 0.95 & 0.88 & 0.87 & 0.87 \\
\hline 2 & 6 & 250 & 0.5 & 2500.15 & 0.66 & 0.70 & 0.66 & 0.59 \\
\hline 3 & 6 & 250 & 1 & 1650.15 & 1.03 & 0.99 & 1.07 & 1.05 \\
\hline 4 & 6 & 250 & 1 & 2500.15 & 0.59 & 0.49 & 0.45 & 0.62 \\
\hline 5 & 6 & 380 & 0.5 & 1650.15 & 0.76 & 0.96 & 0.80 & 0.86 \\
\hline 6 & 6 & 380 & 0.5 & 2500.15 & 0.50 & 0.60 & 0.60 & 0.62 \\
\hline 7 & 6 & 380 & 1 & 1650.15 & 1.16 & 1.11 & 1.05 & 1.13 \\
\hline 8 & 6 & 380 & 1 & 2500.15 & 0.47 & 0.50 & 0.52 & 0.43 \\
\hline 9 & 8 & 250 & 0.5 & 1650.15 & 0.83 & 0.81 & 0.85 & 0.88 \\
\hline 10 & 8 & 250 & 0.5 & 2500.15 & 0.68 & 0.59 & 0.71 & 0.70 \\
\hline 11 & 8 & 250 & 1 & 1650.15 & 0.98 & 1.06 & 1.06 & 1.12 \\
\hline 12 & 8 & 250 & 1 & 2500.15 & 0.48 & 0.42 & 0.52 & 0.43 \\
\hline 13 & 8 & 380 & 0.5 & 1650.15 & 0.86 & 0.81 & 0.77 & 0.78 \\
\hline 14 & 8 & 380 & 0.5 & 2500.15 & 0.72 & 0.61 & 0.62 & 0.67 \\
\hline 15 & 8 & 380 & 1 & 1650.15 & 1.12 & 1.11 & 1.03 & 1.12 \\
\hline 16 & 8 & 380 & 1 & 2500.15 & 0.46 & 0.53 & 0.48 & 0.45 \\
\hline
\end{tabular}

Table 5. Results for the diameter of the inscribed circumference Dc in the experimental plan

\begin{tabular}{|c|c|c|c|c|c|c|c|c|}
\hline \multirow{2}{*}{ Run } & \multicolumn{9}{|c|}{ Experimental design } & \multicolumn{4}{c|}{ Experimental results (trials) } \\
\cline { 2 - 9 } & $\mathbf{d b}, \mathbf{m m}$ & $\mathbf{F}, \mathbf{N}$ & $\mathbf{e}, \mathbf{m m}$ & $\mathbf{i}$ & $\begin{array}{c}\text { Dc, } \mathbf{~ m m} \\
\text { (Side 1) }\end{array}$ & $\begin{array}{c}\text { Dc, } \mathbf{~ m m} \\
\text { (Side 2) }\end{array}$ & $\begin{array}{c}\text { Dc, mm } \\
\text { (Side 3) }\end{array}$ & $\begin{array}{c}\text { Dc, mm } \\
\text { (Side 4) }\end{array}$ \\
\hline 1 & 6 & 250 & 0.5 & 1650.15 & 0.70 & 0.66 & 0.72 & 0.70 \\
\hline 2 & 6 & 250 & 0.5 & 2500.15 & 0.58 & 0.59 & 0.54 & 0.56 \\
\hline 3 & 6 & 250 & 1 & 1650.15 & 1.02 & 1.06 & 1.02 & 1.10 \\
\hline 4 & 6 & 250 & 1 & 2500.15 & 0.60 & 0.77 & 0.68 & 0.83 \\
\hline 5 & 6 & 380 & 0.5 & 1650.15 & 0.58 & 0.72 & 0.58 & 0.62 \\
\hline 6 & 6 & 380 & 0.5 & 2500.15 & 0.53 & 0.54 & 0.62 & 0.52 \\
\hline 7 & 6 & 380 & 1 & 1650.15 & 1.05 & 0.92 & 1.03 & 0.96 \\
\hline 8 & 6 & 380 & 1 & 2500.15 & 0.70 & 0.68 & 0.66 & 0.64 \\
\hline 9 & 8 & 250 & 0.5 & 1650.15 & 0.66 & 0.59 & 0.68 & 0.66 \\
\hline 10 & 8 & 250 & 0.5 & 2500.15 & 0.50 & 0.54 & 0.57 & 0.56 \\
\hline 11 & 8 & 250 & 1 & 1650.15 & 0.97 & 0.90 & 1.03 & 0.97 \\
\hline 12 & 8 & 250 & 1 & 2500.15 & 0.70 & 0.76 & 0.78 & 0.65 \\
\hline 13 & 8 & 380 & 0.5 & 1650.15 & 0.64 & 0.65 & 0.60 & 0.62 \\
\hline 14 & 8 & 380 & 0.5 & 2500.15 & 0.53 & 0.50 & 0.52 & 0.49 \\
\hline 15 & 8 & 380 & 1 & 1650.15 & 0.99 & 0.94 & 0.90 & 0.96 \\
\hline 16 & 8 & 380 & 1 & 2500.15 & 0.69 & 0.67 & 0.68 & 0.70 \\
\hline
\end{tabular}

Table 6. Results for angle $\delta$ between the adjacent cell-borders of the RR in the experimental plan

\begin{tabular}{|c|c|c|c|c|c|c|c|c|}
\hline \multirow[b]{2}{*}{ Run } & \multicolumn{4}{|c|}{ Experimental design } & \multicolumn{4}{|c|}{ Experimental results (trials) } \\
\hline & $\mathbf{d}_{\mathrm{b}}, \mathbf{m m}$ & $\mathbf{F}, \mathbf{N}$ & $\mathbf{e}, \mathbf{m m}$ & $\mathbf{i}$ & $\begin{array}{l}\text { Angle } \delta,{ }^{0} \\
\text { (Side 1) }\end{array}$ & $\begin{array}{l}\text { Angle } \delta,{ }^{0} \\
\text { (Side 2) }\end{array}$ & $\begin{array}{c}\text { Angle } \delta,{ }^{0} \\
\text { (Side 3) }\end{array}$ & $\begin{array}{c}\text { Angle } \delta,{ }^{0} \\
\text { (Side 4) }\end{array}$ \\
\hline 1 & 6 & 250 & 0.5 & 1650.15 & 92.81 & 87.53 & 96.76 & 89.10 \\
\hline 2 & 6 & 250 & 0.5 & 2500.15 & 90.60 & 86.55 & 77.72 & 85.38 \\
\hline 3 & 6 & 250 & 1 & 1650.15 & 84.83 & 132.53 & 78.91 & 79.02 \\
\hline 4 & 6 & 250 & 1 & 2500.15 & 114.90 & 126.22 & 100.36 & 92.29 \\
\hline 5 & 6 & 380 & 0.5 & 1650.15 & 90.37 & 90.59 & 86.72 & 86.17 \\
\hline 6 & 6 & 380 & 0.5 & 2500.15 & 87.70 & 86.52 & 87.95 & 88.46 \\
\hline 7 & 6 & 380 & 1 & 1650.15 & 81.22 & 88.40 & 75.23 & 76.62 \\
\hline 8 & 6 & 380 & 1 & 2500.15 & 138.60 & 151.61 & 113.47 & 100.33 \\
\hline 9 & 8 & 250 & 0.5 & 1650.15 & 85.12 & 85.61 & 89.10 & 90.06 \\
\hline 10 & 8 & 250 & 0.5 & 2500.15 & 89.72 & 91.06 & 86.10 & 92.20 \\
\hline 11 & 8 & 250 & 1 & 1650.15 & 79.69 & 81.05 & 81.71 & 79.91 \\
\hline 12 & 8 & 250 & 1 & 2500.15 & 110.19 & 116.53 & 117.78 & 111.22 \\
\hline 13 & 8 & 380 & 0.5 & 1650.15 & 85.96 & 87.38 & 86.26 & 88.13 \\
\hline 14 & 8 & 380 & 0.5 & 2500.15 & 86.10 & 83.21 & 80.19 & 91.53 \\
\hline 15 & 8 & 380 & 1 & 1650.15 & 76.32 & 76.97 & 77.07 & 79.13 \\
\hline 16 & 8 & 380 & 1 & 2500.15 & 113.36 & 119.53 & 115.35 & 109.51 \\
\hline
\end{tabular}


In order to determine the influence of the regime parameters studied on the process for five-axis BB on steps A and B, the diameter of the inscribed circumference Dc and the angle $\delta$ between the adjacent cell-borders, the following formulae are used:

$$
\begin{gathered}
A v g X_{j}^{\text {low }}=\frac{1}{8} \cdot\left(\sum_{i=1}^{8} X_{i}^{\text {low }}\right) j \\
A v g X_{j}^{\text {high }}=\frac{1}{8} \cdot\left(\sum_{i=9}^{16} X_{i}^{\text {high }}\right) j \\
E f f_{j}^{\left(d_{b}\right),(F),(e),(i)}=A v g X_{j}^{\text {high }}-A v g X_{j}^{\text {low }}
\end{gathered}
$$

where:

- $\left(X_{j}^{\text {low }}\right)_{i}$ - are those $i=1 \ldots 8$ of the values in Tables $3-6$ for $j$ regime parameter $(j=1 \ldots 4)$, calculated for their low values;

- $\left(X_{j}^{\text {high }}\right)_{i}$-are the rest $i=9 \ldots 16$ of the values in Tables $3-6$ for $j$ regime parameter $(j=1 \ldots 4)$, calculated for their high values;

Since in this case there is a four-fold repetition of the results obtained for each of the parameters studied of the RR cells (see Tables $3-6$ for $\left(X_{j}^{\text {low }}\right)_{i}$ and $\left(X_{j}^{\text {high }}\right)_{I}$, the arithmetic mean values, calculated for the corresponding rows of the planned factor experiment, are taken. After being calculated as per formulae (1) and (2) the values for $A v g X_{j}^{\text {low }}$ and $A v g X_{j}^{\text {high }}$, they are also calculated for the magnitude of the effect $E f f_{j}^{\left(d_{b}\right),(F),(e),(i)}$ of the corresponding regime parameter as per formula (3). Using formulae $1-3$ the effects of the four regime parameters of the process are determined and the results are shown in Table 7.

Since there is a four-fold repetition of the results obtained in this study too, the arithmetic mean values of the calculated for the corresponding rows of the planned factor experiment (see Tables $3-6$ ) are taken. The effects of the four regime parameters of the process, determined in this way and the

\begin{tabular}{|c|c|c|c|}
\hline \multirow{2}{*}{$\begin{array}{c}\text { Experimental factor } \\
\text { (BB regime parameter) }\end{array}$} & \multicolumn{3}{|c|}{ Effects for Step $A$} \\
\hline & EffSt $t_{A}^{\text {low }}$ & EffSt $_{A}{ }^{\text {high }}$ & Eff \\
\hline $\mathrm{d}_{\mathrm{b}}, \mathbf{m m}$ & 0.773 & 0.797 & 0.024 \\
\hline $\mathbf{F}, \mathbf{N}$ & 0.800 & 0.770 & -0.030 \\
\hline e, $\mathbf{m m}$ & 0.598 & 0.973 & 0.375 \\
\hline \multirow{3}{*}{$\mathbf{i}$} & 0.816 & 0.754 & -0.062 \\
\hline & \multicolumn{3}{|c|}{ Effects for Step B } \\
\hline & EffSt $t_{\bar{b}}^{\text {low }}$ & EffSt $t_{\bar{B}}$ high & Eff \\
\hline$d_{b}, \mathbf{m m}$ & 0.767 & 0.758 & -0.009 \\
\hline $\mathbf{F}, \mathbf{N}$ & 0.769 & 0.756 & -0.013 \\
\hline $\mathrm{e}, \mathrm{mm}$ & 0.743 & 0.782 & 0.038 \\
\hline \multirow[t]{3}{*}{$\mathbf{i}$} & 0.960 & 0.565 & -0.395 \\
\hline & \multicolumn{3}{|c|}{ Effects for the diameter, $D c$} \\
\hline & $E f f D_{C}$ low & $E f f D_{C}{ }^{\text {high }}$ & Eff \\
\hline$d_{b}, m m$ & 0.735 & 0.707 & -0.028 \\
\hline $\mathbf{F}, \mathbf{N}$ & 0.740 & 0.702 & -0.038 \\
\hline $\mathrm{e}, \mathrm{mm}$ & 0.597 & 0.845 & 0.248 \\
\hline \multirow[t]{3}{*}{ i } & 0.819 & 0.623 & -0.197 \\
\hline & \multicolumn{3}{|c|}{ Effects for Angle, $\delta$} \\
\hline & $E f f \delta^{\text {low }}$ & Effo high & Eff \\
\hline $\mathrm{db}, \mathbf{m m}$ & 95.172 & 91.970 & -3.201 \\
\hline $\mathbf{F}, \mathbf{N}$ & 93.829 & 93.312 & -0.517 \\
\hline e, $\mathbf{m m}$ & 87.770 & 99.372 & 11.602 \\
\hline i & 85.822 & 101.32 & 15.499 \\
\hline
\end{tabular}
results, are shown in Table 7.

Table 7. Effects of the regime parameters in five-axis BB 
Based on the calculated data for the resulting effects from Table 7, the corresponding graphical interpretations, shown on Fig. 4, a-h, are made. In order to rank the regime parameters by degree of significance, Pareto-histograms are constructed, using the halves of the absolute values of the Eff $f_{j}$ effects in accordance with formula (3). As a result, Pareto-histograms and cumulative curves are obtained, shown on Fig. $4 \mathrm{a}-\mathrm{d}$, arranged in descending order by the degree of significance of the regime parameters.

a)

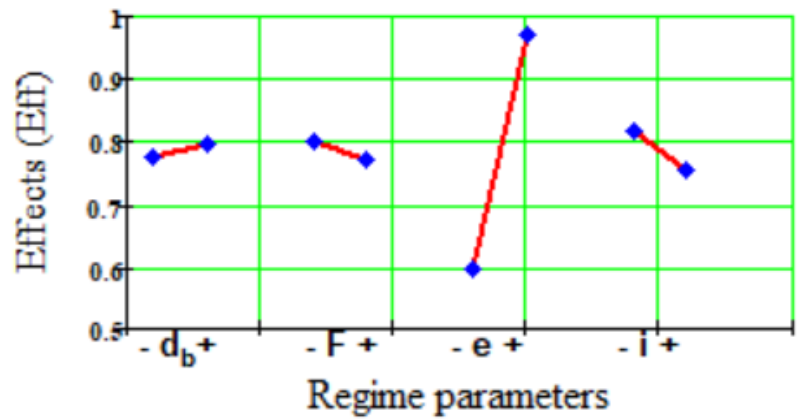

c)

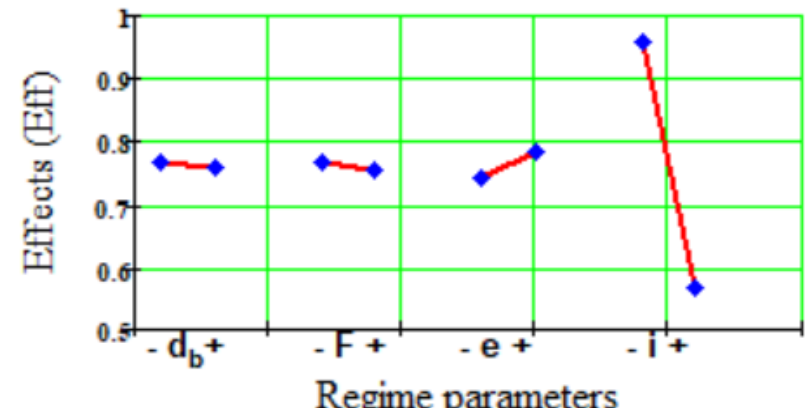

e)

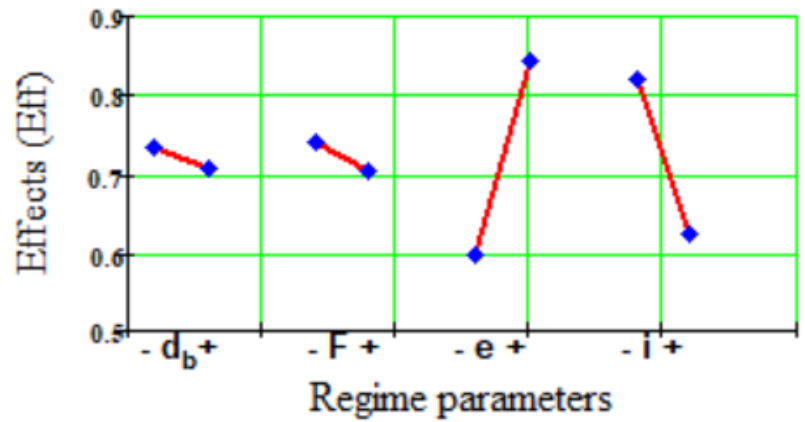

g)

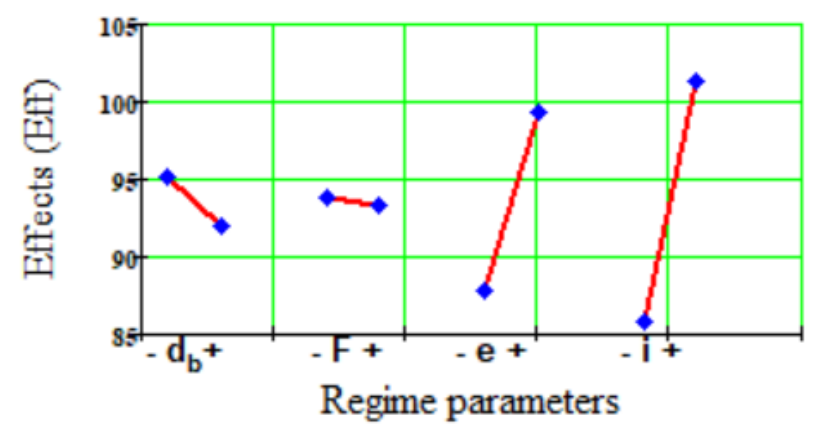

b)

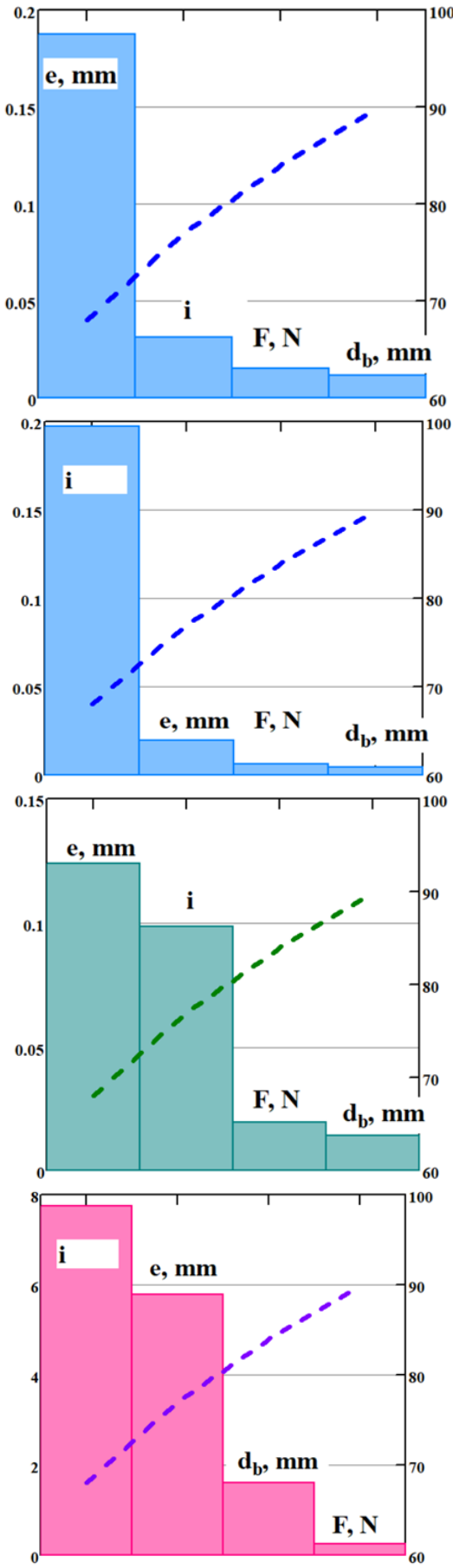

Fig. 4. Effect diagrams and Pareto-histograms of the influence of the regime parameters of the five-axis BB process on:: a), b) Step A; c), d) Step B; e), f) Diameter Dc; g), h) Angle $\delta$.

From the results obtained from Table 7 and Fig. 4, a - h, it is clear that:

- On step A of the RR cells the greatest effect is caused by the regime parameter of the BB process $e, \mathrm{~mm}$, when it increases from 0.5 to $1 \mathrm{~mm}$, the step also increases. Analyzing the data in Table 7, it 
can be seen that the measured steps A have close dimensions to the set low and high levels of $e(0.5$ and $1 \mathrm{~mm}$ ). The rest of the regime parameters do not have great effect on step A;

- On step B of the RR cells the greatest effect is caused by the regime parameter of the BB process $i$, when it increases from 1650.15 to 2500.15 , the step decreases. Analyzing the data in Table 7, it can be seen that the measured steps B corresponds to the low and high levels of $i$. This is logical as the highest the value of parameter $i$, the denser the arrangement of the sine waves of the motion trajectory of the deforming element, consequently this step will be obtained with lower value. The rest of the regime parameters do not have great effect on step B.

- The diameter of the inscribed circumferences Dc, $\mathrm{mm}$ in the RR cells, is an integral criterion for measuring their sizes, as compared to steps A and B. As it can be seen on Fig. 4, e, f, a significant effect on it is caused by both parameters of the regime $e$ and $i$, and their direction of effect remains the same as in steps A and B (see Fig. 4.10, a - d). At lower values of $e$ and higher values of $i$, the RR cells obtained are of smaller size, and vice versa. The other two regime parameters $F$ and $d b$ do not have a great effect on the diameter Dc.

- The angle $\delta$ between two adjacent cell-borders of RR can be used to characterize the shape of the cells of the relief obtained on the processed surface. As it can be seen from Table 6, it obtains values in two areas: the first area, which changes within the range of $80-95^{\circ}$ (for the rows from the experiment 1-3, 5-7, 9-11 and 13-15) and the second area, in which it obtains values $105-150^{\circ}$ (rows 4, 8, 12 and 16). If these results are compared to the corresponding images of RR from Appendix 5, it becomes clear that at angle $\delta=80-95^{\circ}$ cells of a shape close to a rectangle are obtained, and at angle $\delta=105-150^{\circ}$, they are of a shape close to a hexagon. Comparing the latter with the combinations of low and high levels of the regime parameters from the experimental plan in table 6 , it is seen that the bigger angles (or the RR cells with hexagonal shape) are obtained, when both regime parameters, $e$ and $i$, have high values. This is also confirmed by the calculated effects from table 7 and the diagrams, shown on Fig. 4, g, h.

\subsection{Identification of the regime parameters of the five-axis BB process that significantly influence the dimensions and the shape of the RR cells}

An additional statistical check is performed to determine the so-called "threshold" value of the effect, which distinguishes the significantly affecting from the insignificantly affecting factors of the experiment through a Dispersion (ANOVA) analysis (Antony, 2014). A standard calculating methodology is used, based on the calculating procedure in MathCAD 15.0 (PTC).

For a given level of confidence $\mathrm{p}=(1-\alpha)^{*} 100=95 \%$, and degrees of freedom $\mathrm{df}_{\mathrm{A}}=1$ and $\mathrm{df}_{\mathrm{Er}}=$ 59, the critical value of Fisher is determined $\mathrm{F}_{\alpha}=4.004$.

The calculated values of the dispersion analysis made are shown in tables $8-11$ for determining the regime parameters, significantly affecting the parameters of the cells: steps A and B, diameter Dc and angle $\delta$.

From the results obtained for the Fisher's criterion (F-test) from the dispersion analyses, shown in Tables $8-11$, it becomes clear that:

- On step A of the RR cells a great effect causes the regime parameter „Amplitude of the sine waves $e, \mathrm{~mm}$ "of the BB process, whose F-test $=245.061$. Here the Fisher value F-test $=5.733$ of the regime parameter "Number of the sine waves $-\mathrm{i}^{\text {“ }}$ also exceeds the determined threshold value $F \alpha=4.004$, which although with a much lower effect than $e$, also determines it as significant. The Fisher values of the other two regime parameters do not exceed the threshold value, and can be considered as insignificantly affecting;

- On step B of the RR cells a great effect causes the regime parameter „Number of the sine waves - $\mathrm{i}^{\text {“ }}$ of the BB process, whose F-test $=196.207$. here, however, the Fisher values of the other three regime parameters do not exceed the threshold, and can be considered as insignificantly affecting;

- On the diameter Dc of the RR cells main effect cause the two regime parameters: „Amplitude of the sine waves $-e, \mathrm{~mm}^{\text {“ }}$ with F-тест $=224.59$ and ,Number of the sine waves $-\mathrm{i}^{\text {“ }}$ with F-test $=141.605$, but also Fisher F-test $=5.394$ for „Nominal deforming force $-\mathrm{F}, \mathrm{N}$ “ exceeds a little the significance

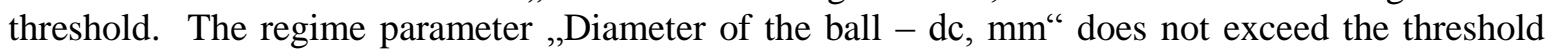
value, therefore it is considered as insignificantly affecting. 
Table 8. Results from ANOVA for the significance of the effect of the regime parameters on step A.

\begin{tabular}{|c|c|c|c|c|c|}
\hline Parameters & $\begin{array}{c}\text { Sum of } \\
\text { squares } \\
\text { SScr }\end{array}$ & $\begin{array}{c}\text { Degrees of } \\
\text { freedom } \\
d f_{A}, d f_{E r}\end{array}$ & $\begin{array}{c}\text { Mean squares } \\
\text { MSE }\end{array}$ & F-statistic & $\begin{array}{l}\text { P-value-Probability } \\
\text { of rejecting the fac- } \\
\text { tor based on its F- } \\
\text { statistic when in fact } \\
\text { it is significant }\end{array}$ \\
\hline Diameter of the ball tool - $\mathrm{db}, \mathrm{mm}$ & 0.009 & 1 & 0.009 & 1.008 & 0.319 \\
\hline Nominal deforming force - $\mathrm{F}, \mathrm{N}$ & 0.014 & 1 & 0.014 & 1.547 & 0.218 \\
\hline The amplitude of the sine waves $-\mathrm{e}, \mathrm{mm}$ & 2.252 & 1 & 2.252 & 245.061 & 0 \\
\hline Number of sinewaves - $i$ & 0.062 & 1 & 0.062 & 5.733 & 0.012 \\
\hline Error & 0.542 & 59 & 0.009 & - & - \\
\hline Total & 2.88 & 63 & - & - & - \\
\hline
\end{tabular}

Table 9. Results from ANOVA for the significance of the effect of the regime parameters on step B.

\begin{tabular}{|l|c|c|c|c|c|}
\hline \multicolumn{1}{|c|}{ Parameters } & $\begin{array}{c}\text { Sum of } \\
\text { squares }\end{array}$ & $\begin{array}{c}\text { Degrees of } \\
\text { freedom }\end{array}$ & Mean squares & F-statistic & $\begin{array}{c}\text { P-value-Probability } \\
\text { of rejecting the factor } \\
\text { based on its F-statis- } \\
\text { tic when in fact it is } \\
\text { significant }\end{array}$ \\
\hline Diameter of the ball tool - db, mm & 0.001 & 1 & 0.001 & 0.105 & 0.748 \\
\hline Nominal deforming force - F, N & 0.003 & 1 & 0.003 & 0.200 & 0.656 \\
\hline The amplitude of the sine waves - e, mm & 0.024 & 1 & 0.024 & 1.860 & 0.178 \\
\hline Number of sinewaves - i & 2.501 & 1 & 2.501 & 196.207 & 0 \\
\hline Error & 0.752 & 59 & 0.013 & - & - \\
\hline Total & 3.281 & 63 & - & - & - \\
\hline
\end{tabular}

Table 10. Results from ANOVA for the significance of the effect of the regime parameters on the diameter Dc.

\begin{tabular}{|c|c|c|c|c|c|}
\hline Parameters & $\begin{array}{c}\text { Sum of } \\
\text { squares } \\
\text { SScr }\end{array}$ & $\begin{array}{c}\begin{array}{c}\text { Degrees of } \\
\text { freedom }\end{array} \\
d f_{A}, d f_{E r}\end{array}$ & $\begin{array}{c}\text { Mean squares } \\
\text { MSE }\end{array}$ & F-statistic & $\begin{array}{l}\text { P-value-Probability } \\
\text { of rejecting the fac- } \\
\text { tor based on its F- } \\
\text { statistic when in fact } \\
\text { it is significant }\end{array}$ \\
\hline Diameter of the ball tool - $\mathrm{db}, \mathrm{mm}$ & 0.013 & 1 & 0.013 & 2.897 & 0.094 \\
\hline Nominal deforming force - F, $\mathrm{N}$ & 0.024 & 1 & 0.024 & 5.394 & 0.024 \\
\hline The amplitude of the sine waves - e, mm & 0.981 & 1 & 0.981 & 224.590 & 0 \\
\hline Number of sinewaves - $\mathrm{i}$ & 0.619 & 1 & 0.619 & 141.605 & 0 \\
\hline Error & 0.258 & 59 & 0.004 & - & - \\
\hline Total & 1.894 & 63 & - & - & - \\
\hline
\end{tabular}

Table 11. Results from AOVA for the significance of the effect of the regime parameters on the angle $\delta$.

\begin{tabular}{|c|c|c|c|c|c|}
\hline Parameters & $\begin{array}{c}\text { Sum of } \\
\text { squares } \\
\text { SSCV }_{\text {C }}\end{array}$ & $\begin{array}{c}\text { Degrees of } \\
\text { freedom } \\
d f_{A}, d f_{E r}\end{array}$ & $\begin{array}{c}\text { Mean squares } \\
\text { MSE }\end{array}$ & F-statistic & $\begin{array}{l}\text { P-value-Probability } \\
\text { of rejecting the fac- } \\
\text { tor based on its F- } \\
\text { statistic when in fact } \\
\text { it is significant }\end{array}$ \\
\hline Diameter of the ball tool - $\mathrm{db}, \mathrm{mm}$ & 163.981 & 1 & 163.981 & 0.898 & 0.347 \\
\hline Nominal deforming force - $\mathrm{F}, \mathrm{N}$ & 4.279 & 1 & 4.279 & 0.023 & 0.879 \\
\hline The amplitude of the sine waves $-\mathrm{e}, \mathrm{mm}$ & 2153.517 & 1 & 2153.517 & 11.798 & 0.001 \\
\hline Number of sinewaves - $i$ & 3843.442 & 1 & 3843.442 & 21.056 & 0 \\
\hline Error & 10769.691 & 59 & 182.537 & - & - \\
\hline Total & 16934.91 & 63 & - & - & - \\
\hline
\end{tabular}

- On the angle $\boldsymbol{\delta}$ of the RR cells a significant effect cause again the two regime parameters: „Amplitude

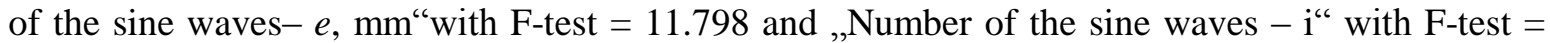
21.056, the latter being dominant. The Fisher values of the other two regime parameters do not exceed the threshold value, therefore they can be considered as insignificantly affecting. 


\section{Conclusions}

Based on the results obtained for the shape and dimensions of the resulting RR cells after five axis $\mathrm{BB}$ process, the following conclusions can be made:

- Step A of the RR cells is mainly affected by the regime parameter „Amplitude of the sine waves - e, $\mathrm{mm}$ “ of the BB process and to a lesser extent by the regime parameter „Number of the sine waves i“;

- On step B of the RR cells great effect is caused by the regime parameter „Number of the sine waves $-\mathrm{i}$ “, and for the other three regime parameters it is found out that they have insignificant effect;

- On the diameter Dc of the RR cells main affect cause the two regime parameters: „Amplitude of the sine waves $-\mathrm{e}, \mathrm{mm}^{\text {“ }}$ and „Number of the sine waves $-\mathrm{i}$ “. The regime parameter „Nominal deforming force - F, N", although exceeding a little the significance threshold, can be considered, together with

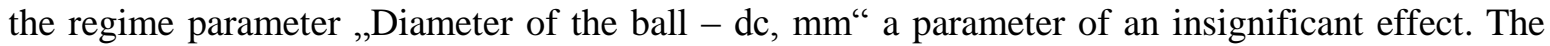
diameter of the circumference, inscribed in the cell Dc, mm, can be used as an integral criterion, with the help of which to determine the overall dimensions of the RR cells, instead of using steps A and $\mathrm{B}$, because, as it can be seen from Fig. 4, e, $\mathrm{f}$ and Table 10, its value is significantly affected by the two regime parameters $e$ and $i$

- On the angle $\delta$ between two adjacent cell-forming structures of RR cells again a significant effect is caused by the two regime: „Amplitude of the sine waves - e, mm“ and „Number of the sine waves i“, the latter being dominant. The Fisher values of the other two regime parameters do not exceed the threshold value, therefore they can be considered as insignificantly affecting.

Summarizing the results obtained, it can be concluded that the assumption that the shape and the overall dimensions of the RR cells in five-axis $\mathrm{BB}$, as per the scheme proposed, will be mainly affected by those parameters of the process (i.e. $e$ and $i$ ), which are related to the setting of the shape and the characteristics of the polyline, defining the motion trajectory of the tool on the non-planar surface, is confirmed. Respectively, the other two regime parameters (F, N and dc, mm), related to the plastic deformation on the surface layer of the processed surface, although obtaining for some of the results from the dispersion analysis Fisher-assessments as significantly affecting, they can be ignored during subsequent optimization studies of the process, thus simplifying these studies in terms of time and resources used.

\section{References}

Shiou, F. J., \& Chen, C. H. (2003). Freeform surface finish of plastic injection mold by using ballburnishing process. Journal of Materials Processing Technology, 140(1-3), 248-254.

Shiou, F. J., \& Chuang, C. H. (2010). Precision surface finish of the mold steel PDS5 using an innovative ball burnishing tool embedded with a load cell. Precision Engineering, 34(1), 76-84.

Георгиев Д.С., Славов С. Д. \& Димитрова Т. Д. (1999). Моделиране на зависимостите на грапавостта и повърхностната твърдост от режимите на ВППД, при обработването на детайли от алуминиеви сплави , II МНТК Машиностр. техн. '99 рег. с-я на НTC - Варна

Георгиев. Д. С. \& Славов С. Д. (2003 а). Влияние на режима на провеждане на процеса плоско вибрационно повърхностно пластично деформиране върху параметрите на грапавостта на плоски стоманени повьрхнини притежаващи регулярни микрорелефи от IV вид. $\mathrm{cn}$. Машиностроителна техника и технологии, изд. на ТО на НТС-Варна и ТУ-Варна, ISSN 135612-0859 стр. 8 - 14

Георгиев Д. С. \& Славов С. Д. (2001). Оптимизация параметрите на грапавостта на плоски повърхнини посредством използване на ВППД, като довършваща обработка, сб. докл. VI MK AMTECH, Созопол, том 2. с. 40 - 50. 
Георгиев. Д. С. \& Славов С. Д. (2003 b). Влияние на режима на провеждане на процеса ВППД върху параметрите на грапавостта на плоски стоманени повърхнини притежаващи РМР от IV вид, cn. MTT изд. ТО на НTC Варна ISSN 1312-0859 с. 3-9.

Георгиев. Д. С. \& Славов С. Д. (2003 с). Изследване на влиянието на режимните параметри при изпълнение на процеса ВППД върху основните параметри на качеството на плоски повърхнини от алуминиева сплав-дуралуминий, $c n$. MTT изд. TO на HTC-Варна ISSN 1312-0859

Георгиев Д.С. \& Славов С. Д. (2011). Методика за определяне на границите на формиране на еднородни РМР получени чрез ВППД на равнинни повърхнини, $c n . M T T$ к.2 ,изд. ТО на НTC-Варна, ISSN 1312-0859,c.94-98

Иванов, Е. Г., Опокин, В. Г., Равилов, Р. Г., \& Самойленко, В. М. (2014). Оценка эксплуатационной эффективности диффузионных покрытий для лопаток турбины современных газотурбинных двигателей. Научный вестник Московского государственного технического университета гражданской авиации, (206).

Климов, В. Г., Жаткин, С. С., Щедрин, Е. Ю., \& Когтева, А. В. (2015). Особенности восстановления геометрии пера лопатки газотурбинного двигателя методом лазерной порошковой наплавки. Известия Самарского научного иентра Российской академии наук, 17(2-4).

Кравченко Г.И. (1978). Гидравлические машины: Турбины и насосы: учебник для вузов / Г.И. Кравченко. М.: Энергия,. 320 с.

Локалов, Г. А., \& Марковский, В. М. (2016). Осевые и центробежные насосы тепловых электрических станций: учебное пособие.

Петрова, М.А., Мехди, С. и Тарасов, А.И., 2015. Анализ условий работы поверхностных слоев рабочих лопаток турбины современных двигателей. Научный вестник Московского государственного технического университета гражданской авиащии, (217 (7))

Таскаев, П. В. (2010). Восстановление моноколес газотурбинных двигателей и агрегатов при повреждении рабочих кромок одной или нескольких лопаток [Электронный ресурс]. Наука и образование., (10).

Славов С.Д. (2001). Приспособление за вибрационно повърхностно пластично деформиране на плоски повърхнини, сб. докл. VI MК АMTECH Созопол, том 2. с. 51 - 56.

Славов С.Д. (2010 а). Възможности на съвременните CAD/CAM системи и металорежещи машини с ЦПУ за формиране на регулярни микрорелефи чрез повърхностно пластично деформиране, Cn. MTT кн. 1, изд. на ТО на НTC-Варна, ISSN 1312-0859; с. 43 - 46.

Славов С.Д. (2010 b). Моделиране на формирането на РМР по плоски повърхнини, обработвани чрез ППД с използване на CAD / CAM системи и металорежещи машини с ЦПУ, cn. MTT кн. 1, изд. на ТО на НTC-Варна, ISSN 1312-0859; с. 47 - 52.

Славов С., Симеонов Н. (2013). Приложение на CAD/CAM софтуерни продукти за създаване и програмиране на специфични инструментални пътища за обработване на равнинни повърхнини, Изв. ТУ-Варна, с-я: Техн. н.,' 1, ISSN 1310-5833, с. 100-107

Славов С. Д. (2014). Определяне степента на влияние на някои параметри на режима на обработване чрез ППД на повърхнини по нова схема върху тримерни критерии на грапавостта, cn. MTT кн. 1, изд. на ТО на НTC-Варна ISSN 1312-0859 с. 14 - 21. 
Сучков А.М., Кършаков, В., Костадинов (1980). Геометрични характеристики на качеството на повърхнини, обработени чрез повърхностно пластично деформиране. Научни трудове на ВИММЕСС-Русе, стр.82-88.

Akkurt, A. and Oval1, İ. (2014) Improving the surface topography of mild steel with the burnishing process, International Journal of Materials Research 105, 10.

A. Sagbas (2011). Analysis and optimization of surface roughness in the ball burnishing process using response surface methodology and desirabilty function. Advances in Engineering Software. 42 992-998.

Antony, J. (2014). Design of experiments for engineers and scientists. Elsevier.

Gharbi, F., Sghaier, S., Morel, F., \& Benameur, T. (2015). Experimental investigation of the effect of burnishing force on service properties of AISI 1010 steel plates. Journal of Materials Engineering and Performance, 24(2), 721-725.https://doi.org/10.1007/s11665-014-1349-1

Grochała, D., Berczyński, S., \& Grządziel, Z. (2014). Stress in the surface layer of objects burnished after milling. The International Journal of Advanced Manufacturing Technology, 72(9-12), 1655-1663 https://doi.org/10.1007/s00170-014-5775-x

Maximov, J.T., Anchev, A. P., Duncheva, G. V., Ganev, N. \& Selimov K. F. (2016) Influence of the process parameters on the surface roughness, micro-hardness and residual stresses in slide burnishing of high-strength aluminium alloys. Journal of the Brazilian Society of Mechanical Sciences and Engineering 2016

Montgomery, D. C. (2017). Design and analysis of experiments. John Wiley \& sons.

Loh N.H., Tam S.C. and Miyazawa, S. (1989 a) A study of the effects of ball burnishing parameters on surface roughness using factorial design, J. Mech. Work. Technol. 18. 53-61.

Loh N.H., Tam S.C. and Miyazawa S. (1989 b) Optimisation of the surface finish produced by ball burnishing, J. Mech. Work. Technol., 19. 101-107.

Babu, P., Ankamma, K., Prasad T., Raju A.V.S., Prasad, N. (2012) Optimization of burnishing parameters and determination of select surface characteristics in engineering materials, Sadhana 37 $503-520$.

Prevéy P. S., Jayaraman N., Cammett J. (2005) Overview of Low Plasticity Burnishing for Mitigation of Fatigue Damage Mechanisms. Proc. of ICSP 9 (Paper 260) Paris. Retrived from https://apps.dtic.mil/docs/citations/ADA444204

Rodríguez A, López de Lacalle L N, Celaya A, Fernzndez A \& Lamikiz A (2011). Ball burnishing application for finishing sculptured surfaces in multi-axis machines. Int. J. Mechatronics Manuf. Syst. 4 220-37

Slavov S. \& Dimitrov D. (2016). Experimental research of the effect of the regular shaped roughness formatted by using new kinematic scheme for surface plastic deformation process on the number of cycles to fatigue failure of stainless steel 304L, ESU, № 4, 2016

Slavov S. \& Dimitrov D. (2018). A study for determining the most significant parameters of the ballburnishing process over some roughness parameters of planar surfaces carried out on CNC milling machine, IManE\&E 2018, MATEC Web of Conferences 178:02005 
Slavov S. \& Iliev I. (2016). Design and FEM static analysis of an instrument for surface plastic deformation of non-planar functional surfaces of machine parts. Fiability \& Durability. Nov 1(2) Academica Brancusi, Targu Jiu, Romania. p. 3-9.

Slavov S. D. (2017). A contemporary approach for obtaining regularly shaped roughness by ball-burnishing process carried out using CNC controlled milling machines. Fiability \& Durability. 1/ 2017. “Academica Brancusi”, Targu Jiu, Romania. 349 - 356.

Slavov S. D. (2018). An Algorithm for Generating Optimal Toolpaths for CNC Based Ball-Burnishing Process of Planar Surfaces, Proceedings of the Second International Scientific Conference (IITI'17). Springer. pp. 365-375

Odintsov L. G. (1987). Hardening and Finishing of Parts by Surface Plastic Deformation. Moscow: Mashinostroenie.

Schneider Yu. G. (2001). Operational properties of parts with regular microshape. St. Petersburg: publishing IVA.

\section{Online sources}

HAAS VF-3 milling center (Date of Access 2019, Mart 1) Retrieved from https://www.haascnc.com/machines/vertical-mills/vf-series/models/medium/vf-3.html

PTC Mathcad, (Date of Access 2019, Mart 1) Retrieved from https://www.ptc.com/en/products/mathcad/new-release

NX - Siemens PLM Software (Date of Access 2019, Mart 1) Retrieved from https://www.plm.automation.siemens.com/global/en/products/nx/ 